\title{
Effects of Visual and Auditory Stimuli on Performance During Sustained Attention Task
}

\author{
Görev SIrasında Verilen Görsel ve Işitsel Uyaranların \\ Sürdürülebilir Dikkat Performansı Üzerinde Etkisi
}

\author{
(D) Yamaç Şendülger ${ }^{1}$, (D) Sevim Adalı${ }^{1}$, (D) Fatma Kılıç ${ }^{1}$, (D) Güliz Akın², (D) İpek Ergönül², (D) Gonca İnanç ${ }^{3}$, (D) Serhat Taşlıca ${ }^{2}$, \\ (D) Murat Özgören ${ }^{4}$, (D) Adile Öniz ${ }^{4}$ \\ ${ }^{1}$ Izmir University of Economics Faculty of Arts and Sciences, Department of Psychology, İzmir, Turkey \\ ${ }^{2}$ Dokuz Eylül University Faculty of Medicine, Department of Biophysics, İzmir, Turkey \\ ${ }^{3}$ Near East University Faculty of Health Sciences, Lefkoşa, KKTC \\ ${ }^{4}$ Near East University Faculty of Medicine, Department of Biophysics, Lefkoşa, KKTC
}

Keywords

Sustained attention, vigilance, visual stimulus, auditory stimulus

Anahtar Kelimeler

Sürdürülebilir dikkat, uyanıklık, görsel uyaran, işitsel uyaran

Received/Geliş Tarihi : 12.12 .2018 Accepted/Kabul Tarihi : 23.07.2019

doi:10.4274/meandros.galenos.2019.03521

Address for Correspondence/Yazışma Adresi: Murat Özgören MD,

Near East University Faculty of Medicine, Department of Biophysics, Lefkoşa, KKTC

Phone : +90 2324124498

E-mail : murat.ozgoren@gmail.com

ORCID ID: orcid.org/0000-0002-7984-2571

(C) Meandros Medical and Dental Journal, Published by Galenos Publishing House.

This is article distributed under the terms of the

Creative Commons Attribution NonCommercial 4.0

International Licence (CC BY-NC 4.0).

\begin{abstract}
Objective: Although many studies are investigating the effects of stimuli on sustained attention performance, only a few studies compare auditory, visual and neutral conditions. Thus, this study aimed to investigate the effect of visual and auditory stimuli on performance during sustained attention task.

Materials and Methods: Twenty-six volunteers participated in this study. Participants executed sustained attention task in three different sessions. In the "auditory" session, participants listened to a highly paced folk music during the Mackworth Clock test. In the "visual" session, happy emoticons were presented around the test screen. In the "neutral" session, the test was carried out without any extra stimulus. The order of sessions was randomised. The time interval between sessions was at least 48 hours, and each session took 5 minute. The reaction times of all responses and correct responses and correct response rates were evaluated. Repeated-measures analysis of variance and Friedman tests were used depending on the distribution characteristics of data.

Results: The reaction times of all responses or correct responses alone did not differ significantly among sessions. The correct response rates were $91.18 \%, 89.74 \%$ and $89.24 \%$ for the auditory, neutral and visual sessions, respectively. However, no statistically significant difference was found when these sessions were compared. Conclusion: Music was expected to improve performance in a sustained attention test, which is not complex but difficult because of monotony, like Mackworth Clock test. Visual stimuli are expected to hamper performance, as they share the modality of the test. Although data had this trend, no statistically significant difference was found. Further research with increased number of participants and more difficult Mackworth Clock test, by extending its duration and using different types of music and visuals, is warranted.
\end{abstract}

Öz

Amaç: Literatürde uyaranların sürdürülebilir dikkat performansına etkilerini inceleyen çalışmalar bulunmasına rağmen, görev sırasında işitsel-görsel-nötr durumlarda sürdürülebilir dikkat performansını kıyaslayan araştırmalar kısıtlıdır. 
Bu araştırmada sürdürülebilir dikkat görevi esnasında uygulanan görsel ve işitsel uyaranların görev performansına etkilerinin araştırılması hedeflenmiştir.

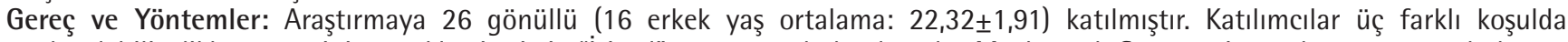
sürdürülebilir dikkat görevini gerçekleştirmiştir. "İşitsel" oturumunda katılımcılar Mackworth Saat testi uygulaması sırasında horon müziği dinlemiş, "görsel" oturumda görsel alan içerisinde testle birlikte mutlu yüz ifadesi ikonları sunulmuştur. "Nötr" oturumda katılımcılar test esnasında ek bir uyarana maruz kalmamıştır. Oturumların sırası seçkisizleştirilmiştir. İki oturum arasında en az 48 saat ara verilmiştir ve her bir oturum yaklaşık beş dakika sürmüştür. Tüm yanıtların ve doğru yanıtların tepki süreleri ile doğru yanıt oranları değerlendirilmiştir. Veri gruplarının dağılım özelliklerine göre tekrarlayan ölçümlerde ANOVA ve Friedman testleri kullanılmıştır.

Bulgular: Tüm yanıtların veya sadece doğru yanıtların tepki süreleri incelendiğinde oturumlar arasında istatistiksel olarak anlamlı fark bulunamamıştır. Doğru yanıt oranları incelendiğinde "işitsel" uyaran eşliğinde doğru yanıt yüzdesinin \%91,18; "nötr" oturumda \%89,74; "görsel" uyaran eşliğinde \%89,24 olduğu görülmüştür. Ancak veriler karşılaştırıldığında oturumlar arasında istatistiksel olarak anlamlı fark bulunamamıştır.

Sonuç: Mackworth Saat testi gibi karmaşık olmayan, ancak tekdüzelik nedeniyle zor olan bir sürdürülebilir dikkat testi esnasında müziğin performansı arttırıcı etkisi olacağı düşünülmüştür. Görsel uyaranların ise test ile aynı modaliteyi paylaştığı için performansı düşürmesi beklenmiştir. Veriler bu trendi gösterse de istatistiksel olarak anlamlı fark gösterilememiştir. Katılımcı sayısı artırmak, Mackworth Saat testinin süresini uzatarak zorluğunu artırmak, farklı tiplerde müzik ve görseller kullanmak gibi yöntemlerle araştırmanın ilerletilmesi planlanmaktadır.

\section{Introduction}

Attention is a state of wakefulness/awareness or alertness where we focus on a stimulus among many and, combine all our emotions and thoughts on that stimulus. Attention is classified into four types: sustained attention, selective attention, divided attention, and alternating attention. Sustained attention is the ability to focus on a stimulus until an action is completed. Students who focus on course materials for a long time while studying for finals or who read a book can be examples for sustained attention (1,2). Degangi and Porges (3) stated that sustained attention consists of three stages that include attention getting, attention holding, and attention releasing. Distracting factors cause disturbances in sustained attention. Engaging in other things during studying or daydreaming while reading can be an example for the disturbances in sustained attention. Vigilance, an active attention situation, can be defined as being alert to danger or emergency, and being conscious. Attention can be distracted more quickly towards positive valence and neutral words, whereas more slowly towards negative valance words (4). This may be caused by the negative stimuli which can be a distress signal and can be related to the survival instinct. This may be due to the fact that the danger-containing stimuli draw attention to itself completely (5).

Sustained attention has been investigated under many different conditions. Sustained attention is quite important for tasks that require continuous visual information processing such as reading, and driving (6). Armstrong and Greenberg (7) examined the performances of individuals in various cognitive activities such as spatial problem solving, reading comprehension, and linguistic processing speed in four different television watching sessions. Significant decreases in reading comprehension, spatial problem solving, and cognitive performance measurements were observed in television watching sessions. Also, a decrease in cognitive performance was observed during performing complex and difficult tasks while watching television. Another study investigated the effects of background television on the Continuous Performance Task (CPT) which is used as a measure of sustainable attention. CPT was administered to the participants in two sessions, with or without the presence of background television. As a result, it has been found that the presence of background television has no impairing or enhancing effect on CPT performance (8). However, Lysaght reported an increase in sustainable attention in the presence of low noise in the background. Lysaght investigated the effects of the noise level (high or low) and noise quality (white or variable noise) on vigilance level. It has been found that performance on low-demanding tasks with the presence of varied music have been improved (9).

Wang (10) examined the effects of music on sustained attention and perceived cognitive fatigue by measuring participants' performance and perceived mental workload in two different conditions which 
are silence and preferred/popular music. Participants' performance generally increased in preferred music condition. In the silent condition, large fluctuations between sessions were observed, while inter-session performance remained constant without sequence effects in the preferred music condition. The results showed that music improves sustainable attention performance and reduces the perceived mental workload.

Shih et al. (11) considered that background music could increase employee satisfaction and productivity and they investigated the effects of music with or without lyrics on attention. The Chu Attention test was administered while listening to music with or without lyrics in the background. The results showed that music with lyrics had significant negative effect on attention and performance. For this reason, they reported that music without lyrics should be preferred in working places since it reduces the attention less and increases the satisfaction in work environment.

Wolfe and Noguchi (12) investigated the use of music for sustain attention of young children in kindergarten under the conditions of auditory distractions. Participants were randomly assigned to one of four conditions which are spoken story with no distraction, spoken story with distraction, musical story with no distraction, and musical story with distraction. Participants were asked to recall some actions and animals after the story telling. The results showed significant differences between the spoken story with distraction condition and the musical story with distraction condition. The musical story with distraction increased attention and engagement compared to spoken story with distraction. The results of the study indicated that the use of music with young children could improve vigilance within educational settings.

Involuntary attention to emotional sounds has been studied in a cross-modal Oddball task where participants categorized angry and frustrated emoticons. Before each emotion, they were exposed to a tone of $80 \%$ in standard tone or $20 \%$ in a nonstandard tone (angry or disappointed). Some of the sounds that they were exposed to in non-standard tones were compatible with the following emoticon (e.g. angry tone and angry emoticon) while others were incompatible (13). The results showed that the emotional content of non-standard tones was effective in the processing of emotion only in trials in which the sound and emoticon were compatible. In other words, the emotion given by music increased emotion perceived from emoticon.

A study was conducted to examine the benefits of musical attention control training (MACT) on psychiatric patients. In MACT, participants were asked to listen to musical exercises that help focused, selective, sustained, and alternating attention. Experimental group received an additional 30-min MACT whereas the control group continued their regular psychiatric therapy. In the study, participants in experimental group outperformed the participants in control group in terms of selective, sustained, and alternating attention (14). This study showed that prolonged music listening can enhance sustained attention. Thus, this study made us think that listening to music may have an impact on sustained attention even it is not prolonged.

Berger and Cassuto (15) aimed to measure whether adolescents with attention deficit hyperactivity disorder (ADHD) were affected more by visual and auditory distractors on CPT than control group and to measure which distractor was more effective for diagnosis of ADHD. The omission errors in the CPT were used to measure the degree of difficulty in sustained attention. The results revealed that ADHD group made significantly higher omission errors in the presence of only visual distractor condition and in the combined visual and auditory distractors condition compared to no distractor condition. On the other hand, distractors did not influence CPT performances in the healthy control group.

Modi (16) studied the effect of background music on attention among clinically diagnosed patients with Parkinson's disease. In the study, there were three experimental conditions which are performing a given task under instrumental music, lyrical music, and no music. The results showed that performing a task under instrumental music condition results in better attention than conditions of no music and lyrical music. Thus, in our study we selected an arousing instrumental music to see whether it has a booster effect on attention.

In the related literature, there is no sufficient number of studies that examines the effects of visual and auditory stimuli on sustained attention in the same study. Apart from the studies in the literature, 
this study aims to investigate the possible positive effect of auditory and visual stimuli on sustained attention task performance.

\section{Materials and Methods}

\section{Participants}

This study was performed in Human Factors Laboratory of Dokuz Eylül University, Department of Biophysics. In this study, 32 healthy participants between the age of 20-27 were recruited for the protocols. Six participants were excluded from the study for failing to complete the sessions. In total, data from 26 participants (16 male; mean: 22.32 \pm 1.92 years) were evaluated. Participants filled the Turkish version of The Symptom Checklist (SCL-90R) before all of the sessions in order to determine their previous diagnosis of any psychiatric or neurological disorders (17-19). All participants have normal hearing, and normal or corrected-to-normal vision and did not suffer from color blindness. Participants signed the written informed consent form and filled the personal information form prior the sessions. Participants' consumption of alcohol, coffee, or any other drugs or medication were questioned since they may have an effect on test performance. In the cases where participants were under the influence of any of these, their recordings were postponed to another day. Prior to each session, participants also filled the Turkish version of The State-Trait Anxiety Inventory State form (STAI-TX1) in order to determine their anxiety levels $(20,21)$. The study has been approved by the Clinical Ethical Committee of Dokuz Eylül University.

\section{Procedure}

Participants were asked to attend three different sessions at an interval of at least 48 hours. These sessions are neutral session, auditory session, and visual stimuli session. Sessions were applied in randomized order to avoid the order effect. Each session lasted an average of five minutes. Mackworth Clock test which is selected from the computer-based PEBL software was applied to the participants (22). The participants performed the task in a quiet and well lit room with only an empty wall, desk, PC screen, mouse, and keyboard in their visual field.

In Mackworth Clock test, sustained attention and vigilance are influential in detecting and following the signals and completion of task. In the test screen, there are 60 small circles ordered in a larger circular pattern like a clock. A red pointer appears inside the small circles one by one in order. Participants were asked to respond by pressing the space key when red point skips a circle.

In the present study, auditory stimuli sessions and visual stimuli sessions were recorded in addition to neutral (no-stimuli) session. Highly paced folkloric music has been selected as auditory stimuli and all participants listened auditory stimuli in a quiet environment through headphones while they were asked to perform Mackworth Clock test. Positive emoticons were used as visual stimuli which were placed around the screen and the wall behind it. Participants were exposed to these emoticons while they were asked to perform Mackworth Clock test. In the control session, Mackworth Clock test applied without any extra stimuli.

\section{Statistical Analysis}

Shapiro-Wilk analysis is performed in order to check for violation of normal distribution. In order to compare group data, One-way repeated measures ANOVA and Friedman test was used for normally distributed and non-normal date, respectively.

\section{Results}

The reaction times of all responses are presented in Table 1 . When they were compared by using repeated measures ANOVA, there was no significant difference between three sessions $[F(1,25)=1.32, p>0.05]$. Also, the reaction times for the correct responses are presented in Table 2. According to Friedman test, there was no statistically significant difference between reaction times of only correct responses $\left[\chi^{2}(2)=1.62\right.$, $p>0.05]$. According to Friedman test, there was no statistically significant difference between the rates

Table 1 . The table shows all reaction times of the participants in Mackworth Clock test

\begin{tabular}{|c|c|c|c|}
\hline & Mean & $\begin{array}{l}\text { Standard } \\
\text { Deviation }\end{array}$ & $\mathbf{n}$ \\
\hline Reaction time NA & 537.09 & 21.71 & 26 \\
\hline Reaction time VA & 530.45 & 25.14 & 26 \\
\hline Reaction time AA & 531.48 & 22.58 & 26 \\
\hline \multicolumn{4}{|c|}{$\begin{array}{l}\text { NA: Neutral All, VA: Visual All, AA: Auditory All } \\
\text { *The reaction time for Neutral All has the longest time. There is a slight } \\
\text { difference between reaction time for Visual All and reaction time for } \\
\text { Auditory All }\end{array}$} \\
\hline
\end{tabular}


of correct responses $\left[\chi^{2}(2)=2.96, p>0.05\right]$. However, when the rates of correct responses were compared, the rates of simultaneous auditory stimulus were found the greatest among all three sessions [Median=95.00, interquartile range $(I Q R)=4.17$ ]. Furthermore, the rates of correct responses of visual stimulus [Median=93.33, IQR= 4.16] were greater than the rates of correct responses of neutral session (Median=95.83, IQR= 12.09).

\section{Discussion}

The present study investigated the possible effects of the visual and auditory stimuli on performance during sustained attention. Three different sessions (visual, auditory, neutral) with the interval of 48 hours were recorded. The results indicated that there were no significant differences between the number of correct answers, congruent reaction times, and overall reaction times among three different sessions. However, a non-significant increase in the correct answers were found in the auditory stimulus session which may indicate a possible positive effect of high paced music.

In related literature, the effect of auditory stimulus on sustained attention have been reported. Lysaght (9) (1982) examined the effects of noise level (high and low) and noise quality (white or changeable noise) on vigilance and reported that low-demanding tasks with the presence of varied music have positive effect on the performance. Wang (10) examined the effects of music on attention and perceived cognitive fatigue and found that music eased the work load and increased performance. Wolfe and Noguchi (12) examined the effects of the auditory stimulus on the sustained attention on children and found that the use of music could improve vigilance in children. Shih

Table 2. The table indicates the reaction times for the correct responses in Mackworth Clock test

\begin{tabular}{|l|l|l|l|} 
& Median & $\begin{array}{l}\text { Interquartile } \\
\text { Range (IQR) }\end{array}$ & $\mathbf{n}$ \\
\hline Reaction time NP & 419.02 & 48.60 & 26 \\
\hline Reaction time VP & 410.48 & 48.24 & 26 \\
\hline Reaction time AP & 418.78 & 50.69 & 26 \\
\hline $\begin{array}{l}\text { NP: Neutral Press, VP: Visual Press, AP: Auditory Press } \\
\text { *The shortest reaction time for correct responses is in the visual } \\
\text { condition. The auditory condition has shorter reaction time for correct } \\
\text { responses than neutral session }\end{array}$ \\
\hline
\end{tabular}

et al. (11) (2016) showed that music without lyrics distracted workers less and provided job satisfaction compared to music with lyrics. Ljungberg et al. (13) (2016) asked participants to categorize the angry and frustrated facial expressions after they were given sound in three different tones. As the result of the study, it was found that the reaction times of the participants slowed down when the auditory stimulus and the emotional content of the facial expressions were matched.

In further researches, it is planned to continue the study by increasing the number of the participants, using different genres of music, and extending the application time of Mackworth Clock test.

\section{Conclusion}

In this research, the effects of the visual and auditory stimuli that were given during the application of Mackworth Clock test on the sustained attention performance were examined. The results of the study showed that there was no statistically significant difference between the reaction times and correct answers of the participants when three sessions were compared (Neutral, Simultaneous Visual Stimulus, and Simultaneous Auditory Stimulus). Nevertheless, it was found that there was a booster effect of high paced folkloric music, that were chosen as auditory stimulus, on correct answers. Therefore, it can be said that music with high pace affects the sustained attention in a positive way. Using only single type of auditory or visual stimulus is one of the limitations of the study. In further studies, the participants can be given a soothing music along with high paced music that has a stimulant feature in a different session in simultaneous with Mackworth Clock test. Thus, the effects of the soothing music and stimulant music on the sustained attention can be compared. Effects of different types of noises or natural sounds can also investigated. Likewise, the effects of the visual stimuli that have different emotions (e.g. scared and happy emoticons) can be given in different sessions while simultaneously applying Mackworth Clock test. Using dynamic figures or videos is another possible method to investigate effects of visual stimuli.

\section{Ethics}

Ethics Committee Approval: The study has been approved by the Clinical Ethical Committee of Dokuz 
Eylül University (decision no: 2017/18-44, date: 13.07.2017).

Informed Consent: Participants signed the written informed consent form and filled the personal information form prior the sessions.

Peer-review: Externally and internally peerreviewed.

\section{Authorship Contributions}

Concept: I.E., M.Ö., A.Ö., Design: I.E., M.Ö., A.Ö., Data Collection or Processing: i.E., M.Ö., A.Ö., G.i.,, S.T., G.A., Y.S.., F.K., S.A., Analysis or Interpretation: I.E., M.Ö., A.Ö., G.I., S.T., G.A., Y.Ş., F.K., S.A., Literature Review: I.E., M.Ö., A.Ö., G.I., S.T., G.A., Y.Ş., F.K., S.A., Writing: I.E., A.Ö., Y.Ş., F.K., S.A., M.Ö.

Conflict of Interest: No conflict of interest was declared by the authors.

Financial Disclosure: The authors declared that this study received no financial support.

\section{References}

1. Chen C-Y, Wang C-J, Chen E-L, Wu C-K, Yang YK, Wang J-S, et al. Detecting Sustained Attention during Cognitive Work Using Heart Rate Variability. In: 2010 Sixth International Conference on Intelligent Information Hiding and Multimedia Signal Processing; 2010 Oct 15-17; Darmstadt, Germany. 2010.p.372-5.

2. Ko LW, Komarov O, Hairston WD, Jung TP, Lin CT. Sustained Attention in Real Classroom Settings: An EEG Study. Front Hum Neurosci 2017; 11: 388.

3. DeGangi G, Porges S. Neuroscience Foundations of Human Performance http://penta.ufrgs.br/edu/telelab/3/sustaine.htm (1990).

4. Estes Z, Adelman JS. Automatic vigilance for negative words in lexical decision and naming: comment on Larsen, Mercer, and Balota (2006). Emotion 2008; 441-57.

5. Yamaguchi M, Harwood SL. Threat captures attention but does not affect learning of contextual regularities. Cogn Emot 2017; 31: $564-71$

6. Rothlein D, DeGutis J, Germine L, Wilmer J, McGlinchey R, Esterman M. Sensitivity to stimulus similarity is associated with greater sustained attention ability. Atten Percept Psychophys 2018; 80: 1390-408.

7. Armstrong GB, Greenberg BS. Background Television as an Inhibitor of Cognitive Processing. Hum Commun Res 1990; 16: 355-86.
8. Cowan M. Sustained attention in the presence of background television: A developmental study. Nova Scotia: Mount Saint Vincent Univ, 1994.

9. Lysaght RJ, Warm JS, Dember WN, Loeb M. Sex differences on a cognitive vigilance task within the context of noise exposure and relative quiet. In: Proceedings of the First Mid-Central Conference on Human Factors Conference (pp191-195) 1984.

10. Wang $M$. The influence of preferred music on vigilance and mental workload. Westerville (OH): Otterbein Univ. 2015.

11. Shih Y-N, Huang R-H, Chiang H-Y. Background music: effects on attention performance. Work 2012; 42: 573-8.

12. Wolfe DE, Noguchi LK. The use of music with young children to improve sustained attention during a vigilance task in the presence of auditory distractions. J Music Ther 2009; 46: 69-82.

13. Ljungberg Korning J, Hjärtström $H$, Sörman D. The impact of emotional deviant sounds on emoji faces in a sustained attention task. In: 57th Annual Meeting of the Psychonomic Society; 2016 Nov 17-20; Boston, USA. 2016; 21.

14. van Alphen R, Stams GJJM, Hakvoort L. Musical attention control training for psychotic psychiatric patients: an experimental pilot study in a forensic psychiatric hospital. Front Neurosci 2019; 13 : 570.

15. Berger I, Cassuto $\mathrm{H}$. The effect of environmental distractors incorporation into a CPT on sustained attention and ADHD diagnosis among adolescents. J Neurosci Methods 2014: 222; 62-8.

16. Modi V. Impact of music on attention among patients with parkinson's disease. EC Psychol Psychiatry 2018; 321-9.

17. Derogatis, LR, Savitz KL. The SCL-90-R and brief symptom Inventory, and matching clinical rating scales. In: M. E. Maruish, editor. The Use of Psychological Testing for Treatment Planning and Outcomes Assessment. Mahwah: Lawrence Erlbaum Associates, 1999: 679-724.

18. Dağ I. Belirti Tarama Listesi (Scl-90-R)'nin Üniversite Öğrencileri için güvenirliği ve geçerliği. Türk Psikiyatr Derg 1991; 2: 5-12.

19. Kılıç M. Belirti Tarama Listesi (SCL-90-R)'nin Geçerlilik ve Güvenirliği. Türk Psikolojik Danışma ve Rehb Derg 1991; 1: 45-52.

20. Spielberger CD. State-Trait Anxiety Inventory: Bibliography. Palo Alto: Consulting Psychologists Press; 1989.

21. Oner N, Le Compte A. Süreksiz Durumluk / Sürekli Kaygı Envanteri El Kitabı. İstanbul: Boğaziçi Üniversitesi Yayınları; 1983.

22. Mackworth NH. The breakdown of vigilance during prolonged visual search. Quarterly Journal of Experimental Psychology 1948; 1: 6-21. 